\title{
Russia and China as Viewed by Russian and Chinese Youth
}

\author{
A.A. Sorokina, M.S. Maximenkova \\ National Research University Higher School of Economics \\ 20 Myasnitskaya Str., Moscow 101000 Russia
}

\begin{abstract}
Russia-China relations are a major research focus in international relations, yet few studies have so far addressed the issue of how the two nations view each other. This study seeks to contribute to closing this gap by focusing on how college-age millennials perceive the counterpart country. We have selected students who have had experience studying abroad, namely Chinese students who have studied in Russia and Russian students who have studied in China. Our findings are based on the analysis of 150 in-depth qualitative narrative interviews conducted with Chinese and Russian students (75 in each group). The study demonstrates that ethnocentric stereotypes prevail and both groups engage in cultural 'othering'. Meanwhile, students from both countries perceive Russian President Vladimir Putin as a central determining factor in shaping Russia-China relations.
\end{abstract}

Key words: Russian students, Chinese students, qualitative research, country perceptions

\section{Introduction}

Over the course of the last decade, Russian-Chinese relations have advanced to a new level, as Russia has begun to view China as its main partner on the international political arena and in economic matters. In July 2017, Russian President Vladimir Putin signed an executive order on awarding the General Secretary of the Communist Party of China, President of the People's Republic of China Xi Jinping the highest order of Russia, the Order of St. Andrew the First-Called, for his distinguished service in strengthening the friendship and cooperation between the peoples of the Russian Federation and the People's Republic of China. In 2017, during his address to the Federal Assembly, Putin described Russia's relationship with China as an 'all-encompassing strategic partnership'.

According to public opinion polls, the majority of Russians (77\%) view China as a strategic partner or ally [1]. $73 \%$ of people in China have a positive attitude towards Russians and Russia [2]. Public opinion polls are a key part of studies in international relations, since the perceptions of citizens of one country of the citi-

(C) Sorokina A.A., Maximenkova M.S., 2020.

(i) This work is licensed under a Creative Commons Attribution 4.0 International License https://creativecommons.org/licenses/by/4.0/ 
zens of another country could indicate certain trends in the developments of relations between nation-states; current public opinion polls among young people also indicate how relations between nation-states can develop in the future, as the current younger generations go on to become policy-makers. This article analyses and interprets perceptions of China among young people in Russia, and perceptions of Russia among young people in China.

Analyzing trends in perceptions among these groups will allow us to understand a starting point of mutual perceptions from which the possible future elites involved in forging Russia-China ties will emerge. The findings presented here are based on an analysis of 150 in-depth qualitative narrative interviews conducted with Chinese students and Russian students (75 with each group). We show that ethnocentric stereotypes prevail and each group engages in cultural "othering," that students from both countries perceive Russian President Vladimir Putin to be a central determining factor in shaping Russia-China relations, and that students are uncertain about how the relationship between the two countries will develop in the future. We also argue that the image of China in the eyes of Russian students and the image of Russia in the eyes of Chinese students are based mostly on elements of soft power.

A vast body of literature is dedicated to the image of contemporary China in the eyes of citizens of other nation-states. These works mostly address how China is depicted in foreign media reports [3], and some of the studies also analyse cross-national opinion polls. Tao Xie and Benjamin I. Page use data from the Pew Global Attitudes Project (hereafter referred to as 'Pew'), which includes data from over 44 countries, and argue that the level of 'freedom' or liberal democracy in a country has no significant impact on how that country's public views other countries. The authors show that the most important determinant of China's image in a country is that country's level of socio-economic development, as measured by the UN Human Development Index. The higher a country scores on the index (controlling for other factors), the less favorable its public's views of China. According to the data, publics in Pakistan, Russia and Lebanon have the most positive perceptions of China [4].

Works dedicated to the image of China and Chinese citizens among Russian citizens focus mostly on studies of populations living along the Russian-China border. Kapitolina Fedorova analyzes the roles of ethnic, social, and linguistic stereotypes in forming the image of Chinese citizens among Russian citizens. According to Fedorova, who studied in-group conversations and interviews conducted in 2008-2010 in the Zabaikalskii territory of Russia and the Chinese city of Manzhouli (Autonomous region Inner Mongolia), Russians living in the RussiaChina border region resort to a large number of cliches about Chinese people, generally exhibit negative attitudes towards this group, and are sometimes shockingly rude. The author argues that this can be explained by a high level of xenophobia in Russia, which is also reflected in a large body of other studies [5]. Alicja Curanovic, for example, argues that the Russians perceived the Chinese state as a smaller threat than the Chinese people. Studies show that Russian citizens 
mostly express concern about demographic factors, i.e. the population of China, which is much larger than that of Russia [6].

A number of other studies are dedicated to the views the Chinese public holds of other countriesт [7]. Jolanda van der Noll и Henk Dekker, for example, conducted a quantitative analysis of polls in China dedicated to perceptions of the USA, the EU, Russia, and Japan in China. The authors conclude that Chinese citizens' attitudes mirror the international relations between China and these four world powers. A great majority of the respondents had a positive to very positive overall attitude towards the EU and Europeans (85\%), Russia and Russians (73\%), the United States and Americans (59\%). The attitude towards Japan and Japanese citizens was predominantly negative [2]. A new body of literature is also addressing the attitudes of younger generations of Chinese citizens who plan to study or have already begin to study abroad. For example, Peter G. Ghazarian has shown that a positive image of a foreign country among Chinese young people has an effect on their readiness to continue their studies in that country, and on their plans for emigration from China [8].

Another body of literature addresses stereotypes associated with various social groups in Russia and in China. These studies of national stereotypes (such as a classical work by Katz and Braly) have focused largely on the question of how far stereotypes are perceived as true by those who voice them, and how far stereotypes are actually grounded in reality [9]. We believe that stereotypes can inform and shape perceptions and reception of new information, thereby determining the emotions and social attitudes of various social groups towards other groups.

Not many studies published in the English language have dealt with the topic of stereotypes of China and of Chinese people. Nonetheless it is important to study such stereotypes in order to understand the image of Chine on the international arena.

Some studies are dedicated to the relationship between the media and negative stereotypes. Bersick, for example, argues that the European Union perceives China increasingly negatively, which has to do with the strengthening of China's position on the international arena and economically, and with the influence of old stereotypes and promotion of new negative stereotypes about China in the mass media [10]. Some researchers have used the phrase "China as-a-menace-to-the world" to describe the stereotypes associated with Chine in the West [11]. Lingling Zhang also studies the influence of media on stereotypes and claims that American college students see China largely as a potential threat to the United States, an image that is formed by media messages [12]. Gordana Blagojević, who studies perceptions among contemporary Serbs about the Chinese, argues that the Chinese widely settled in Serbia in the 1990's, yet knowledge among the Serbian population about this community of migrants largely exists at the level of media information [13].

Boden has pointed out that stereotypes and cliches often emerge due to lack of knowledge. Since citizens of European countries learn about China not through their own experiences but through mediated knowledge transmission, studies have 
shown that mass media play a major role in forming the image of China in the eyes of Europeans. The image of China in Europe is informed very strongly by postcolonial power dynamics and Eurocentrism, which are reflected in the mass media. The formation of stereotypes can be mutual, and come from both sides: "China looks at Europe and the West in general from a Sinocentric viewpoint measuring the West by Chinese standards" [14].

$\mathrm{Li}$ and Worm also note that images of China that emerge and dominate in the realm of public opinion in the West can be traced back to the 1980s. A lack of understanding of contemporary China and the stereotype-ridden image of the country are based on prejudice that can be linked to Eurocentrism and colonialism. The role of the media is crucial here. To improve China's international image and remove the misunderstanding of China, the authors have suggested that China should concentrate on developing soft power. They also mention the ways in which China has worked on its soft power over the past several years [15], a topic that is also addressed in the works of Falk Hartig [16].

Lingling Zhang's study (mentioned above) also shows that stereotypes about Chinese people are mixed. The author studied stereotypes about Chinese people among American college students, and concluded that negative stereotypes include the ideas that Chinese people are prejudiced, arrogant, narrow-minded, corrupt, and not generous. Positive stereotypes found in this study included the ideas that Chinese people are smart, hardworking, inventive, and have good morals [12]. Unlike the previous study, this study is dedicated to perceptions of Chinese people at large, rather than ethnic Chinese people who have immigrated to the country where the study is carried out.

Bob McKercher has developed the themes of Chinese people, stereotypes, and international mobility, and has turned his attention to the interactions between the first generation of mass tourists and the host community in different countries [17]. He notes that residents (host communities) of countries which attract the first generation of mass tourists see the tourists as "laggards, inward looking individuals who are culturally and socially introverted, unworldly and resistant to change". Russia and China became important cases in this study because at the moment of publication of this article, residents of these countries became the first generation of tourists.

While the studies discussed above are dedicated mostly to how residents of Western countries perceive China and Chinese people, other studies have also addressed the image of China in other Asian countries. For example, Larisa Nikitina and Fumitaka Furuoka studied perceptions about China in neighboring Asian countries by conducting a survey meant to uncover cultural stereotypes about China among Malaysian students who are studying the Mandarin language [18]. The authors conclude that the image of China in the eyes of study participants is multifaceted and diverse. The authors note a series of key components of this image (culture, politics, language, history, climate, landscape, economics, religion and the Chinese people) and uncover specific associations with China (e.g. Kung $\mathrm{Fu}$, Shaolin Temple, Great Wall of China, Bird Nest Stadium etc.). 
The existing body of literature dedicated to the image of China and Chinese people and stereotypes of China and Chinese people shows that negative stereotypes dominate positive ones, and that stereotypes are not rooted in a deep knowledge of the culture and history of China. Most authors also conclude that increasing China's soft power can lead to improvements in the image of China on the international arena, and that China is already taking steps in this direction.

The image and stereotypes of contemporary Russia in other countries has also not been studied in-depth in the social sciences. One of the most stimulating studies in this under-studied area is the work of Larisa Zhilina, who surveyed Japanese students about their perceptions of Russia, and Russian students about their perceptions of China. The results show that study participants subscribe to a number of stereotypes about the other country; for example, Japanese students claim that Russia is 'the biggest country in the world,' 'It occupies a huge territory,' it is a 'northern country,' is associated with 'Siberia,' and is the 'country near Hokkaido.' Russia is also perceived as the 'distant neighbor,' 'neither European nor Asian,' and 'geographically, Russia is very much a part of East Asia,' which contrasts with what the Russian respondents would claim [19].

Alexander Bukh also conducted a survey-based study among young people in Southeast Asia, namely in Laos, Thailand, and Vietnam. The starting point of this study mirrors our own: the author seeks out study participants who would become the potential elites of the countries in question, and assumes that perceptions of the countries in this group will influence how the relationship between the countries will develop in the future. The study shows that despite the fact that many years have passed since the collapse of the Soviet Union, young people in the countries from the sample view Russia through the lens of stereotypes associated with the Soviet Union. Some non-Speviet-specific stereotypes were also voiced by the study participants, including Russian food, weather and the nesting doll matryoshka [20].

Several works address stereotypes associated with Russia and Russian people among Chinese people. These studies show that, just like in the case of stereotypes about China, the image is mixed and multifaceted. For example, a survey among Chinese people who work in Russia showed that they associate the positive characteristics of kindness (75\%) and honesty (50\%) with Russians. Negative stereotypes included drunkenness (72.4\%), greed (27.6\%), egoism (25.9\%), and parasitism (20.7\%) [21].

Jolanda van der Noll and Henk Dekker also surveyed Chinese study participants and showed that Chinese people view Russia as peaceful and trustworthy (the study compared Chinese perceptions of Russia with Chinese perceptions of Japan and the USA) [2].

Works that address the topic of how citizens of Russia and of China view each other are mostly historical in their approach, and focus on the development of Russia-China relations on the international arena. T.A. Hsia, for example, has described how Chinese citizens went from holding predominantly negative attitudes towards Russia in the late $19^{\text {th }}$ and early $20^{\text {th }}$ centuries, when Russia was 
perceived as an aggressor state, to viewing Russia not only positively, but as an exemplary society in the latter half of the $20^{\text {th }}$ century [22]. Alexander Lukin also addresses Russia-China relations by studying the attitudes of Russian political elites towards China in the 1990s [23].

Few studies have addressed both attitudes of Russian citizens towards China, and of Chinese citizens towards Russia. There is also a gap in data on attitudes of Russian and Chinese young people towards China and Russia, respectively. If young people do come up in studies, the studies usually refer to the topic of educational migration [24].

This study seeks to close this gap, using a vast data set of qualitative interviews with Russian and Chinese university students. The sections that follow outline the research design and methods, results, analysis, conclusion, and implications of this study.

\section{Research Design}

From June 2017 to February 2018, researchers at the Laboratory of Political Studies of the National Research University Higher School of Economics conducted 150 in-depth qualitative narrative interviews with Chinese students and Russian students (75 with each group).

We interviewed students who are particularly interested in pursuing careers that have to do with developing Russian-Chinese relations on the international arena. We selected Chinese students who were studying at Lomonosov Moscow State University, National Research University Higher School of Economics (NRU HSE), People's Friendship University of Russia (RUDN), the Moscow State Institute for International Relations (MGIMO). Most of the interviewees were bachelors students, or students who were enrolled at a course intended to prepare international students for studies at the aforementioned Russian universities. At the moment of the interview, each of the students had been residing in Russia for a period of about one year. The length of times the students were residing in Russia was important to us because we wanted to control for how longterm stays can affect attitudes towards Russia among foreign students.

We also interviewed students who are from Russia, who study at Lomonosov Moscow State University and the National Research University Higher School of Economics (NRU HSE), who are enrolled in majors dedicated to Asian Studies, and who also study the Chinese language. The majority of the students from Russia who were interviewed in this study had been to China during travels or for language programs.

Each interview lasted approximately one hour. During the interview, interviewees were asked open unstructured questions about the main topics and images they associate with "Russia" and with "China", and about the possibilities for the development of relations between the two countries in the future. We carried out the interviews with Chinese students in Chinese and/or in English, while the Russian students were interviewed in Russian. 
We transcribed each interview and coded the data using qualitative content analysis. During coding, we highlighted the components that make up the image of each country using the following categorizations: cultural and historic elements and traditions, geographic and natural characteristics and demographic elements, everyday behavior norms in society, the political system, social and economic development, important political leaders and international relations.

The first question posed in the interview allowed us to identify the major associations study participants have with the countries they are asked about, and which they think of immediately without much thought (they were asked to name the very first associations that came to mind, without analysing them).

Both Russian and Chinese students, when asked to name the associations they have with the image of China and Russia, named associations that mostly fall within the categories "cultural and historic elements and traditions", "geographic and natural characteristics and demographic elements", and "everyday behavior norms in the two countries". Russian students mostly focused on "cultural and historic elements and traditions" of China (associations that fall within this category was mentioned two times more often by Russian students about China than by Chinese students about Russia). For Chinese students, the dominant category of associations with Russia is the 'geographic and natural characteristics' category.

Table 1

Russia and China as Viewed by Russian and Chinese Youth

\begin{tabular}{|l|c|c|}
\hline Components of the image & $\begin{array}{c}\text { The image of China } \\
\text { among Russian students } \\
\text { (mentions) }\end{array}$ & $\begin{array}{c}\text { The image of Russia } \\
\text { among Chinese students } \\
\text { (mentions) }\end{array}$ \\
\hline $\begin{array}{l}\text { Cultural and historic elements } \\
\text { and traditions }\end{array}$ & $\mathbf{6 5}$ & $\mathbf{3 0}$ \\
\hline $\begin{array}{l}\text { Geographic and natural } \\
\text { characteristics } \\
\text { and demographic elements }\end{array}$ & $\mathbf{5 0}$ & $\mathbf{4 5}$ \\
\hline $\begin{array}{l}\text { Everyday behavior norms } \\
\text { in society }\end{array}$ & $\mathbf{2 0}$ & 6 \\
\hline Political system & 19 & 8 \\
\hline $\begin{array}{l}\text { Social and economic } \\
\text { development }\end{array}$ & 15 & 10 \\
\hline International relations & 12 & 26 \\
\hline Important political leaders & 10 & \\
\hline
\end{tabular}

Source: compiled by the authors.

The analysis presented below is dedicated to the content of each of the categories we have named above in the table (see table 1), and offers a detailed look at the image of China and Chinese citizens in the eyes of Russian students who are interested in China, and, subsequently, at the image of Russia and Russian citizens in the eyes of Chinese students who are interested in Russia academically and professionally. 


\section{The Image of China in the Eyes of Russian Students}

The Russian students emphasized the idea that China is a 'different world' that is difficult for a 'Western person' to understand. Most students who mentioned 'the West' would associate themselves with a closeness to 'the West,' uttering phrases like 'for us, Western people who love democracy and other such things, it is difficult to understand China' (Russian student, female, 20 years old). Some identified China as 'a totally different world' or 'a different planet.' One student claimed that 'China is a whole separate world, from the fact that they are different from us in terms of mentality, to their architecture. What is for us, people of the West, a 'yes,' would be a 'no' for Chinese people; what's white for us is black for them.' The most-mentioned characteristics of China mentioned Russian students in our interviews fall under the category 'cultural and historic elements and traditions,' with 64 mentions in total across all our interviews with Russian students. Russian students noted that Chinese culture is very unique, speaking most often about Chinese food, which is characterised as a 'cult' element of Chinese culture by Russian students. Russian students spoke about Chinese rice, sweet pork, crackers, tea, and noted that in their view, the processes of cooking and eating are treated like a ritual by many Chinese people: 'This is a who ritual for them. For example, if there is an important business meeting, but lunchtime comes around, they will stop all business talks in order to have a meal' (Russian student, male, 18 years old). Other important cultural elements named by Russian students include Chinese calligraphy, the Beijing opera, unique architectural forms, and traditional costumes. At the same time, study participants noted that Chinese culture is very different from European cultures and sometimes people who are not open and ready to see new things can end up confused at some aspects, for example the opera: 'The Peking opera is very distinctive and original, you would never see anything like that anywhere else, all these costumes. I mean, all of these super costumes and the high notes. I mean, if someone who is not really ready for this watches it, then they would not understand anything, or they would just find it very funny. In general, this is something very unique, something that does not exist in other countries' (Russian student, female, 20 years old).

Another key category used to describe China by Russian students includes 'geographic and natural characteristics and demographic elements,' which most often contained students' reflections on the high population density of China. For many students this was one of they key characteristics of China that stands out most in their imaginaries of the country: 'China is people. Many, many people, they are everywhere over there. This country is like an anthill. There are crowds all over the place, people with backpacks and children' (Russian student, female, 20 years old). As we mentioned above, many Russians are more wary of Chinese people than they are of the Chinese state at large. This has to do with demographics: in Russian society fear of Chinese demographic dominance is quite widespread, as people believe that it is possible that 'Chinese people have nowhere to live in China' and 'they will move to Russia.' These worries were also 
voiced by our study participants when they spoke of Russia as a potential country, the territory of which can help China solve its overpopulation problems. Another characteristic mentioned often was the climate of China, such as "extremely hot summers" from their time in the country.

20 study participants also mentioned 'everyday behavior norms in society' in their reflections on China. This category includes mentions of 'open' and 'kind' Chinese citizens who exhibit behavior norms the Russian students were not accustomed to. For example, one of the things Russian students described as being unaccustomed to on their trip to China was the fact that they encountered Chinese citizens who wished to take photographs with the Russian students. The students also mentioned that it is customary for Chinese citizens to help others: 'friendliness among Chinese people. They understand that we don't understand very much about their culture and their language, and even so they try to help' (Russian student, female, age 19). According to the Russian study participants, another characteristic of Chinese people is their ability to create a dense crowd and not to let anyone get ahead: 'Even in Shanghai there's not really the kind of culture we have here. For example, they don't know that people should first exit the metro car, and only after that should new passengers enter it - instead there's a giant collision' (Russian student, female, 20 years old). Some of the study participants also noted that they noticed certain habits among people in China, like rolling up T-shirts in hot weather: 'I associate China with men who roll up their T-shirts in the heat and show their stomachs to everyone around' (Russian student, male, 21 years old). Some students said that they were surprised that in China parents constantly scold and criticise their children, and employers criticise their employees: 'I was not prepared for the fact that I would constantly be scolded and criticized. My parents spoiled me, and at school I was always praised... this is impossible to imagine in China. It's considered that the only way to motivate someone is to harshly criticize them, otherwise the person will not understand what they are doing wrong and how to do it better' (Russian student, male, 20 years old).

Study participants also noted characteristics of the Chinese political system, which came up a total of 19 times in the study among Russian students; they would usually mention communism or the communist party of China, without going into detail: 'I associate China first and foremost with the color red, then with the Community Party of China, since this is the core, because it is codified in the constitution and in other laws' (Russian student, male, 20 years old).

Social and economic development was mentioned 15 times in the study, with reference to the uneven development of China and the coexistence of very poor areas and modern skyscrapers right next to each other. Students spoke about the sharp contrasts they encountered in China: 'If you walk in the center of a city, you see all these skyscrapers, everything is very beautiful and developed, but, literally, if you just turn the corner and go on a street to the right, making just one turn - then you will see a narrow dirty small street, people's things will be hanging outside, cables everywhere, women would be washing the laundry in washbasins. And all of this is right in the city center. Everything is so mixed there, like tall buildings, and tra- 
ditional architecture, and small old houses. This is very surprising to everyone. In China riches are right next to poverty' (Russian student, 20 years old). Most of the students also noted that China is a very promising country which is developing at an extremely rapid pace. One of the elements students found very promising was China's foreign policy, or China's standing in international relations, which was mentioned 12 times in the study. The Russian students noted that China is one of the leading countries on the international arena. Students who participated in the study also mentioned important political leaders 10 times, mostly citing Mao Zedong rather than Xi Jinping, China's current President and General Secretary of the Chinese Communist Party: "When I think of the word 'China' the first things that come to mind are the color red and Mao Zedong, because in school we studied Soviet-Chinese relations" (Russian student, male, 19 years old).

\section{The Image of Russia in the Eyes of Chinese Students}

The main component of the image of Russia in the eyes of Chinese student is Russia's 'geographic and natural characteristics and demographic elements,' which were mentioned 56 times by the Chinese students who participated in this study. Within this category, Russia's climate was mentioned most often, more specifically cold Russian winters. Students said that this climate is unusual for them because China is not as cold. 'For me, Russia is always cold and snowy, though I also lived here during the summer. We, Chinese people, are not used to this kind of weather, especially since I am from the south of China' (Chinese student, male, 23 years old). Students also mentioned the deep impressions they have gotten from fields and forests in Russia; one study participant spoke of his first impressions of the country in the following manner: 'I needed to take a drive to Tyumen [a city in Russia], and during the whole drive I only saw forest out of the car window. Five hours of nothing but trees. In Chine there are not that many forests, which is probably why this surprised me the most' (Chinese student, male, 21 years old). Chinese students often compared the ecological situation in Russia to that of China, positively evaluating Russia's clean air, which is clean even in Moscow, and lamenting the fact that air pollution is one of China's most pressing problems today.

When describing the associations they have with Russia, Chinese students also emphasized 'everyday behavior norms in society' in Russia. This category came up 45 times in the study in interviews with Chinese students. Some of the key characteristics of everyday behavior norms they mentioned included kindness, niceness, and responsiveness among Russians. These associations are related to personal encounters with people; Chinese students would describe at length how local residents in Russia would help them find a bus stop or a shop, for example. At the same time, Chinese students noted that Russians do not like to smile. In their interviews, the students often called Russians 'combative', explaining that they mean that Russians have a harsh character and strong willpower. Chinese students also spoke about the importance of alcohol for Russians; some study par- 
ticipants recalled 'typical Russian vodka' and that 'all Chinese people know that vodka is your national drink' (Chinese student, male, 19 years old).

Some students made note of differing norms of study in Russian and Chinese universities. Chinese students said that they found it very good that students in Russian can openly debate their lecturers and express their own opinions without fear of being punished: 'We don't have that in China. There, the students have to listen to the teacher and never challenge them. I also like that the lecturers try to convey information to each and every student; if you didn't understand something, they will explain it to you again, and this is extremely helpful for me in particular because in almost every lecture that is something that I cannot quite understand and learn right away. In China the teacher does not care whether you understood something or not, the learning process there is aimed more at self-education. That is, you go home and then you try to figure out the topic for yourself.' (Chinese student, male, 19 years old).

For many of the Chinese students who participated in the study, Russia is associated with its 'cultural and historic elements and traditions,' which were mentioned 30 times. This was mostly related to classical Russian literature. Study participants would recall that they read these classics in school, for example: 'Of course, all Chinese people have to read parts of novels or short stories in school, such as War and Peace or Anna Karenina' (Chinese student, female, 21 years old). Some students also mentioned that they are familiar with the $19^{\text {th }}$ century Russian poet Alexander Pushkin, who they also learned about in school. With regard to history, in their interviews Chinese students most often recalled and referred to the Soviet period. Many study participants notes that Chinese people are well acquainted with Soviet leaders, such as Joseph Stalin, Nikita Khrushchev Leonid Brezhnev, and Vladimir Lenin. In addition, study participants said that Russian films about war are very popular in China. According the study participants, Chinese pensioners are especially interested in the Soviet period: ' $\mathrm{Xi}$ Jinping is friends with Putin, and because of this there are many tourist groups from China that consist of pensioners here. For them, this is like the USSR, they learned Russian when they were children, and for them Russia and the USSR are part of their childhood. Therefore they want to come here and see the Red Square or the Hermitage, they want to remember their years of youth' (Chinese student, male, 20 years old).

Chinese students would also mention Russian food in their reflections about the country, which mostly included borsch, blini, and syrniki. Several students also mentioned national holidays: 'Holidays and days off, New Year's, Easter - all these days create such a warm, cozy atmosphere for me' (Chinese student, female, 23 years old). The Russian holiday Maslenitsa ${ }^{l}$ received special attention from

\footnotetext{
${ }^{1}$ Maslenitsa is an Eastern Slavic religious and folk holiday, celebrated during the last week before Great Lent. Sometimes they call it the 'pancake week', because in this time everyone has to cook and eat pancakes.
} 
study participants: 'I think that Maslenitsa is the best reflection of Russian traditions' (Chinese student, female, 22 years old).

An important component in the image of Russia in the eyes of Chinese students are the important political leaders of Russia, which were mentioned 26 times. Every third study participant (among Chinese students), when reflecting on their associations with Russia, mentioned Russian President Vladimir Putin. Chinese students noted that Vladimir Putin can often be seen on Chinese television. 'Chinese people think that he can do a lot. For example, he plays hockey, foes fishing, goes hunting, can shoot a gun. He's a universal person. Many Chinese people say that Russia would be a very different country without Putin' (Chinese student, female, 21 years old). Study participants overwhelmingly claim that Chinese citizens have a very positive outlook on Putin and consider him to be a strong and strong-willed leader who is also a friend of Xi Jinping. Students spoke of the fact that when Putin came to power, Russia-China relations significantly improved, and if he remains in power, then the two countries will keep up their positive relationship.

Another major characteristic of Russia mentioned by Chinese students alongside the topic of Vladimir Putin is Russia's standing on the international arena, in international relations. This was mentioned 10 times by study participants. The Chinese students who participated in this study had a positive outlook on Putin's actions on the international arena, claiming that they like 'his tough politics.' Few Chinese study participants mentioned social and economic development (8 mentions) or characteristics of Russia's political system (mentioned 6 times). Only a few study participants mentioned that Russia has found itself in a difficult economic situation.

\section{The Future of Russia-China Relations in the Eyes of Chinese and Russian Students}

After we made asked about the first associations that came to mind among study participants when speaking about the country in question, we went on to ask the students about how Russia-China relations are likely to evolve in the future.

Despite the fact that most of the study participants both on the Russian side and on the Chinese side positively evaluate the current state of affairs between Russia and China, their evaluations of how the relationship will progress were more varied.

First, Russian students had trouble brainstorming about the development of Russia-China relations because of a tendency among Russian youths to focus on a short-term planning horizon. Studies have shown that young people in Russia have difficulty imagining what the future has in store for Russia domestically in the next 10-15 years, and they even have trouble predicting what their own future has in store for them individually. This uncertainty spills over onto their perceptions of the international arena. Efforts to discuss possible scenarios for the next 15 years were met with the students' refusal to engage in the activity. They justi- 
fied their inability to answer such questions by saying that this time frame is too long, 'everything can change many times over during that many years, and it is difficult to predict things in Russia'. Many students noted that the development of Russia and the development of Russia's standing on the international arena will largely depend on the future of Russia's presidency: 'Everything depends on the president; whoever will end up in power in the country, that will determine what kind of country this will be' (Russian student, male, 20 years old).

It is important to note that Russian students had fewer difficulties in speaking about the future of China. They expressed certainty that China will develop rapidly, this will involved technological advances and the advance of the Chinese language to becoming and international language. When Russian students spoke about the future of China, they would often begin to voice certain fears that would be exacerbated in a context of hesitation and uncertainty about the future of Russia. If the first associations with the image of China were usually tied with cultural aspects of the country, when asked about the future, Russian students would stress that China is a great power: 'I think that right now China is slowly joining the ranks of countries that rule economically, if I may use this phrase; countries that set the standards around the world, countries the whole world depends on. It is possible that China will be one of the competitors of the USA. China is already pretty much posing a certain threat' (Russian student, female, 21 years old).

Russian students also concluded that the friendship between Russia and Chine is possible only while they do not have anything to compete for. When asked what brings Russia and China together at the current moment, Russian students could not answer and mostly resorted to generalising about mutual interest in oil. 'Today, I believe, judging by the news and by what I heard from Chinese people, it seems we get along. I would like to hope so' (Russian student, female, 20 years old).

Russian students believe that the major factor that determines the type of relationship Russia has with Chine is the reorientation of all foreign policy towards Asia in a context of strained relations between Russia and the EU, as well as between Russia and the USA. 'The main task of Russia right now is "turning" towards the East, because relations with China today are becoming more of a partnership. Russia-China relations will continue to develop. Russia won't have the same kind of cooperation with the West as it had before' (Russian student, male, 18 years old). Many Russian study participants noted that because of the current power dynamics on the international arena, China is very important to Russia: 'Because the whole world has turned away from us. I mean that we turned the world away from us ourselves, and this has happened working on the assumption that the Russians and the Chinese are friends forever' (Russian student, male, 20 years old).

According to Chinese students, Russia-China relations will most likely remain friendly in the future. The main determinant of friendly relations between the two countries is believed by study participants to be the will of Russian President Vladimir Putin. Many Chinese students hope that Putin will make it easier for Chinese citizens to enter Russia, especially those looking to study at Russian universities. At the same time, the Chinese study participants voiced their concerns about the devel- 
opment of Russia-China relations in the event of a new president in Russia: 'If the political leadership of Russia changes, then it will be impossible to predict how he will be disposed towards China' (Chinese student, female 24 years old).

At the same time, Chinese students often noted over the course of the study that many Chinese people who live in China are wary about Russia, mostly due to how Russia is depicted in Chinese media. Chinese students claimed the on Chinese television channels Russia is mostly depicted as a military power, which has caused many people in China to allegedly associate Russia with rockets and tanks, according to study participants. 'If you do an internet search for 'Russia,' you would see photographs of the Russian army, paratroopers, rockets and tanks, fleet, and a parade on the Red Square. This parade is very famous in China, they show it every year on television. That is why many people think that Russia is all about tanks and rockets, and there's a parade every day!' (Chinese student, male, 19 years old).

It is important to note the Chinese students interviewed for this study do not perceive Russia in terms of its military capacity or weapons. Instead, some students cited military strength as a stereotype held by Chinese citizens who live in China with regard to Russia. This demonstrates that studying in Russia possibly results in less militarized lens through which the visiting students view the country.

\section{Conclusions and Implications}

A major factor that could bring about constructive relations between countries is apositive perception between the countries' populations of one another. The image of China in the eyes of Russian students, and the image of Russia in the eyes of Chinese students are based mostly on elements of soft power. Almost none of our study participants spoke about the country they were interviewed about in terms of its military capacity, which leads us to conclude that there is fertile ground for the positive development of cooperation between the two countries in the future.

However, it is important to note that our sample was limited in terms of the types of students we interviewed: the Chinese students who participated in the study are studying Russian and are interested in Russia, and they have experience interacting with Russian students and other Russian citizens. The Russian students we interviewed are also interested in China and the Chinese language. However, we cannot say that the students exhibited deep or nuanced knowledge of the other country and based many of their answers on commonly held stereotypes. For Russian students who study the Chinese language, China is a country they perceive as differing greatly from European countries, as 'another world' where it is very hot, with a high concentration of the population, and where people eat rice, drink tea, and live in areas where skyscrapers mix with small traditional houses. For Chinese students who study the Russian language, Russia is a country where it is always very cold, where people are harsh and militant and do not like to smile. Notably, when Russian and Chinese students were asked about associations with the countries, in their answers they would often resort to discussions of the population of the country in question specifically; both Russian and Chinese students speak 
of 'the Chinese' or 'the Russians' and their characteristics, often citing stereotypes, such as 'Chinese people photograph everyone' or 'Russians love drinking vodka'.

This tendency for potential specialists in Russia and China to resort to stereotypes about the 'other' population may prove to be a barrier for constructive dia$\log$ in the future. Students are least informed about social and economic characteristics of the two countries, and about how the political system of the respective countries functions. This is necessary knowledge for those who plan to study and to inform policy on Russia-China relations in the future.

Russian and Chinese students perceive the development of Russia-China relations as something that is intricately connected to the figure of Russian President Vladimir Putin. Both Russian and Chinese students exhibit only very superficial knowledge of economic, cultural, and educational projects the two countries are involved in together.

At the moment, Russia and China must work on developing and improving their educational programs that focus on Russia-China relations. Overcoming stereotypes and creating a constructive image of other countries is possible only in a context conducive to the mutual exchange of knowledge. Educational programs that focus on China and on Russia in Russia and in China respectively should include the themes of cultural communication, socio-political characteristics, and economic ties, and should steer students beyond stereotypical thinking.

\section{References}

[1] Rossiya - Kitaj - SSHA: otnosheniya v strategicheskom treugol'nike'. Russian Public Opinion Research Centre (WCIOM), (7 February 2017). Available from: https://wciom.ru/ index.php?id=236\&uid=116055. Accessed 11.06.2018 (In Russ.).

[2] Noll J., Dekker H. A Comparative Analysis of Chinese urban Citizens' attitudes towards the EU, the United States, Russia and Japan. International Relations. 2016; 30 (4): 456-472.

[3] Syed N.A. The Effect of Beijing 2008 on China's Image in the United States: A Study of US Media and Polls. The International Journal of the History of Sport. 2010; 27 (16-18): 28632892.

[4] Xie T., Page B.I. What Affects China's National Image? A cross-national study of public opinion. Journal of Contemporary China. 2013; 22(83): 850-867.

[5] Fedorova K. Speaking With and About Chinese Language Attitudes, Ethnic Stereotypes and Discourse Strategies in Interethnic Communication on the Russian-Chinese Border. Civilisations. 2013; 62 (1-2): 71-89.

[6] Curanovic A. Why don't Russians fear the Chinese? The Chinese factor in the selfidentification process of Russia. Nationalities Papers. 2012; 40 (2): 221-239.

[7] Dong L. Chinese Perceptions of the European Union. Journal of Contemporary China. 2014; 23 (88): 756-779.

[8] Ghazarian P.G. Country Image and the Study Abroad Destination Choice of Students from Mainland China. Journal of International Students. 2016; 6(3): 700-711.

[9] Katz D., Braly K. Racial stereotypes of one hundred college students. The Journal of Abnormal and Social Psychology. 1933; 28(3): 280-290.

[10] Bersick S. Perceptions of Asia in Europe. Asia Europe Journal. 2010; 8 (2): 244-255.

[11] Ng S.H., Ye J., Lee C. Media Discourse on Globalization in China: A Social-Psychological Analysis. Journal of Language and Social Psychology. 2011; 30 (2): 139-157. 
[12] Zhang L. Stereotypes of Chinese by American college students: media use and perceived realism. International Journal of Communication. 2015; 9: 1-20.

[13] Blagojević G. Contemporary Serbian stereotypes about the Chinese in Belgrade: When you say China, I think about Block 70 or... Zbornik Matice srpske za drustvene nauke. 2009; 129: 47-6.

[14] Boden J. Mass media: Playground of stereotyping. International Communication Gazette: Formerly Gazette. 2016; 78 (1-2): 121-136.

[15] Li X., Worm V. Building China's Soft Power for a Peaceful Rise. Journal of Chinese Political Science. 2011; 16 (1): 69-89.

[16] Hartig F. Confucius Institutes and the Rise of China. Journal of Chinese Political Science. 2012; 17 (1): 53-76.

[17] McKercher B. The Roots of Stereotypes about Tourists. Society. 2008; 45: 345-347.

[18] Nikitina L., Furuoka F. 'Dragon, kung fu and Jackie Chan...'? stereotypes about China held by Malaysian students. Trames. A Journal of the Humanities and Social Sciences. 2013; 17 (2) (67/62): 175-195.

[19] Zhilina L. Public attitude and mutual perceptions: Japan and Russia. Political Science Journal. 2015; 10 (1-2): 1-30.

[20] Bukh A. Russia's Image and Soft Power Resources in Southeast Asia: Perceptions among Young Elites in Laos, Thailand and Vietnam. Contemporary Southeast Asia: A Journal Of International \& Strategic Affairs. 2016; 38 (3): 445-475.

[21] Vasil'eva K., Ostrovskij A., Alagueva T. The Image of Russians in the Eyes of the Chinese and the Image of the Chinese in the Eyes of Russians on Contiguous Territory. Far Eastern Affairs. 2007; 35 (4): 104-114.

[22] Hsia T.A. Demons in Paradise: The Chinese Images of Russia. The Annals of the American Academy. 1963; 349: 27-37.

[23] Lukin A. Russia's Image of China and Russian-Chinese Relations. East Asia. 1999; 17 (1): 5-39.

[24] Bislev A. Student-to-Student Diplomacy: Chinese International Students as a Soft-Power Tool. Journal of Current Chinese Affairs. 2017; 2: 81-109.

Article history:

The article was submitted on 18.12.2019.

The article was accepted on 02.02.2020.

Научная статья

\title{
Образы России и Китая во взаимных представлениях российской и китайской молодежи
}

\author{
А.А. Сорокина, М.С. Максименкова \\ Национальный исследовательский университет «Высшая школа экономики» \\ Мясниикая улииа, д. 20, Москва, Россия, 101000
}

\begin{abstract}
Аннотация. Российско-китайские отношения находятся в центре внимания исследователей международных отношений. Тем не менее изучение представлений россиян о Китае и китайцев о России в работах представлено недостаточно. Данная работа нацелена на то, чтобы восполнить этот пробел. В фокусе - взаимные представления о странах среди студенческой молодежи. В основе работы лежит анализ 150 глубинных интервью, проведенных с китайскими студентами, специализирующимися на изучении России, и российскими
\end{abstract}


студентами, специализирующимися на изучении Китая (по 75 в каждой группе). В статье показано, что во взаимных представлениях друг о друге преобладают стереотипы, а определяющим фактором в развитии российско-китайских отношений респонденты из обеих стран считают российского президента В.В. Путина.

Ключевые слова: российские студенты, китайские студенты, качественное исследование, представление о стране

\section{История статьи:}

Статья поступила в редакцию 18.12.2019.

Статья принята к публикации 02.02.2020.

\section{Информация об авторах:}

Сорокина Анна Андреевна - кандидат политических наук, ведущий научный сотрудник Института прикладных политических исследований, доцент факультета социальных наук Национального исследовательского университета «Высшая школа экономики» (ORCID ID: 0000-0002-6412-2045) (e-mail: aasorokina@ hse.ru).

Максименкова Марина Сергеевна - директор Центра политических исследований и экспертизы Института прикладных политических исследований, преподаватель факультета социальных наук Национального исследовательского университета «Высшая школа экономики» (ORCID ID: 0000-0003-2148-9522) (e-mail: mmaksimenkova@ @se.ru).

\section{Information about the authors:}

Anna A. Sorokina - Leading Research Fellow of Laboratory for Political Studies, Associate Professor, National Research University Higher School of Economics (Russian Federation) (ORCID ID: 0000-0002-6412-2045) (e-mail: aasorokina@hse.ru).

Marina S. Maximenkova - Director of Centre for Political Studies and Assessments in Institute for Applied Political Studies, lecturer, National Research University Higher School of Economics (Russian Federation) (ORCID ID: 0000-0003-2148-9522) (e-mail: mmaksimenkova@ hse.ru).

\section{Для цитирования:}

Sorokina A.A., Maximenkova M.S. Russia and China as Viewed by Russian and Chinese Youth // Вестник Российского университета дружбы народов. Серия: Политология. 2020. Т. 22. № 1. C. 144-160. DOI: 10.22363/2313-1438-2020-22-1-144-160

\section{For citation:}

Sorokina A.A., Maximenkova M.S. Russia and China as Viewed by Russian and Chinese Youth. RUDN Journal of Political Science. 2020; 22 (1): 144-160. DOI: 10.22363/2313-1438-2020-22-1144-160 